\title{
Virulence Analysis and Influence of Soil Type and Agronomic Practices with Respect to Incidence of Ganoderma Wilt of Coconut in Southern Karnataka, India
}

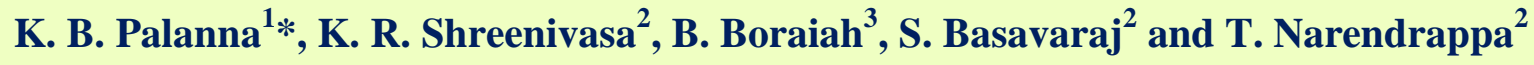 \\ ${ }^{1}$ ICAR-AICRP on Small Millets, Project Coordinating Unit, University of Agricultural \\ Sciences, GKVK, Bengaluru-560065, Karnataka, India \\ ${ }^{2}$ Department of Plant Pathology, UAS, GKVK, Bengaluru-560065, Karnataka, India \\ ${ }^{3} Z A R S$, University of Agricultural Sciences, GKVK, Bengaluru-560065, India \\ *Corresponding author
}

\author{
A B S T R A C T
}

K e y w o r d s
Coconut,
Ganoderma wilt,
Virulence, Disease
Severity Index,
Soil type
Article Info
$\begin{aligned} & \text { Accepted: } \\ & 12 \text { March } 2020 \\ & \text { Available Online: } \\ & 10 \text { April } 2020\end{aligned}$

\section{Introduction}

Coconut (Cocos nucifera L.) belonging to family Arecaceae are important commercial crop of India providing livelihood to a substantial number of farm families. Coconut, the versatile palm popularly known as 'King of Palms', 'Tree of Heaven', 'Tree of life',
Ganoderma wilt of coconut, caused by Ganoderma spp. is one of the most important constraints limiting coconut production and productivity in Southern Karnataka. The incidence of Ganoderma wilt of coconut during the year 2015-16 ranged from 0 to 47 per cent in southern dry tracts of Karnataka among 356 gardens surveyed. Tumkur recorded maximum incidence $(16.75 \%)$ followed by Chitradurga $(14.86 \%)$ and Hassan $(11.12 \%)$ among four districts surveyed. Ganoderma wilt was noticed in mono crop as well as mixed crop of coconut and incidence of disease was more with coconut and arecanut intercropping compared to sole crop. However, the percentage of incidence with particular cropping system varied greatly from garden to garden. Among the different soil types, maximum incidence $(14.28 \%)$ was observed in sandy soils followed by red soils $(13.52 \%)$. Canal water irrigated gardens accounted maximum (19.20\%) incidence. Similarly, gardens under flood irrigation recorded maximum $(17.78 \%)$ incidence. The gardens under regular cultivation recoded maximum incidence compared to un cultivated gardens. The disease incidence with respect to age of the palms revealed that maximum (14.92\%) incidence was noticed in age group of 30-50 years followed by 15-30 years of age. Virulence of 9 Ganoderma isolates of coconut tested under pot culture revealed that isolate $\mathrm{CG}_{11}$ recorded maximum (62.50) DSI at 9 months after inoculation followed by $\mathrm{CG}_{7}$ and $\mathrm{CG}_{8}$ which accounted 56.25 DSI and were on par with each other, which were found to be virulent compared to other isolates. 
and production (Rethinam and Taufikkurahman 2002). In India coconut palms are grown in an area of 1.94 million hectares with a production of 14811.4 million nuts and a productivity of 7608 nuts/ha. annually.

Coconut palms are normally affected by various biotic and abiotic stresses resulting in drastic reduction in yields. Among the various biotic stress that affect coconut and arecanut production in India, Basal Stem Rot (BSR) or Ganoderma wilt caused by Ganoderma applanatum Pers and G. lucidum Leys. Karst. is a major constraint in coconut and arecanut production, especially in dry tracts of Southern Karnataka. The disease is reported from various places all over the tropical world viz., India, Srilanka, West Indies, Seycheles, Guam etc.

Though the disease was first recorded by Dr. Butler in the beginning of $20^{\text {th }}$ century and later by Venkatanarayan (1936) from Karnataka, a severe outbreak occurred in 1652 in Thanjavur district of Tamil Nadu, and hence named as Thanjavur wilt. The disease is also reported from Andhra Pradesh (Basal stem rot), Kerala, Maharastra, Gujarath and Orissa (Bhaskaran,1994;Wilson et al., 1987). The disease incidence was maximum (62.5\%) in coconut palms cultivated in sandy soils and red soils while it was negligible $(1.21 \%)$ and nill in black soils, paddy bunds or fish pond bunds (Srinivasalu et al., 2003).

Naik et al., (2000) reported that the disease severity ranged from 17.16 to 76.92 per cent in Arsikere Taluk of Hassan in Karnataka. However, not much study has been done relating to etiology and incidence of Ganoderma wilt with respect to soil types and agronomic practices in southern dry tracts of Karnataka. Hence the present study was undertaken to elucidate the disease incidence with respect to soil types, agronomic practices and cropping systems followed by farmers in disease hotspot areas of Karnataka and to establish the pathogenicity of Ganoderma. Further, assessment of disease incidence and severity with respect to different agronomic practices followed by farmers in disease hotspot areas of Karnataka, will be useful to take/design further remedial measures to combat the disease, thereby coconut and arecanut production will be enhanced.

Therefore, investigations on Ganoderma wilt of coconut and arecanut with respect to pathogen variability and disease management were under taken with the following objectives. Hence, present study was under taken to elucidate the disease incidence with respect to different agronomic practices followed by farmers in disease hotspot areas of Karnataka.

\section{Materials and Methods}

\section{Survey for the incidence Ganoderma wilt of coconut}

In southern Karnataka, major coconut growing districts, taluks and villages were selected for survey (Table 1). Based on stratified random sampling technique in each garden 100 palms uniformly were observed and number of palms infested with basal stem rot (Ganoderma wilt) and other major diseases were recorded and expressed as Disease Incidence (\%).

$$
\begin{array}{cc}
\text { Disease } & \begin{array}{c}
\text { No. of plants } \\
\text { infected }
\end{array} \\
\text { Incidence }(\%)= & \begin{array}{c}
\text { Total no. of plants } \\
\text { observed }
\end{array}
\end{array}
$$

During the course of survey, different agronomic practices followed by the farmers for cultivation of coconut and arecanut and soil type, method of irrigation etc were recorded and correlated with disease incidence. In addition, farmers practices 
(ITK) for management of BSR coconut and other related information were also documented (Fig. 1).

\section{Collection of diseased root samples/stem bit and sporocarps of coconut}

The major coconut growing districts and talukas were selected and numbers of gardens/villages are selected based on stratified sampling technique. Different parts of the coconut palms such as diseased root bits/stem bits affected by Ganoderma wilt showing typical symptoms and sporocarps were collected from infected palms from different places of southern Karnataka (Table 2 ). The samples were labeled and packed in polythene bags for the purpose of isolation of the causal organism.

\section{Isolation and designation of the causal organism isolates}

Infected roots/ stem bits collected from infected palms were washed thoroughly with sterile water and cut into small bits/pieces and were surface sterilized in 0.1 per cent mercuric chloride for 30 seconds and washed three times serially in sterile distilled water to remove the traces of mercuric chloride. After surface sterilization diseased specimens were kept in sterilized bags along with wet cotton under room temperature for about 8 to 10 days. After 8 to 10 days of incubation period, slight mycelial growth was observed and that was transferred into Potato Dextrose Agar (PDA) medium. The inoculated plates were incubated at room temperature $\left(28{ }^{\circ} \mathrm{C} \pm 2{ }^{\circ} \mathrm{C}\right)$ for 3-5 days to facilitate growth of the fungus. Later, the bit of fungal growth was transferred to PDA slants. The pure culture of the fungus was obtained by following hyphal tip culture technique under aseptic conditions. The isolated Ganoderma isolates of coconut were designated as $\mathrm{CG}_{1}, \mathrm{CG}_{2}, \mathrm{CG}_{3}, \mathrm{CG}_{4}, \mathrm{CG}_{5}$, $\mathrm{CG}_{6}, \mathrm{CG}_{7}, \mathrm{CG}_{8}, \mathrm{CG}_{9}, \mathrm{CG}_{10}, \mathrm{CG}_{11}, \mathrm{CG}_{12}$,
$\mathrm{CG}_{13}, \mathrm{CG}_{14}, \mathrm{CG}_{15}, \mathrm{CG}_{16}, \mathrm{CG}_{17}, \mathrm{CG}_{18}, \mathrm{CG}_{19}$, $\mathrm{CG}_{20}, \mathrm{CG}_{21}, \mathrm{CG}_{22}, \mathrm{CG}_{23}$ and $\mathrm{CG}_{24}$. The cultures so obtained were stored in refrigerator at $4{ }^{\circ} \mathrm{C}$ for further studies and they were cultured periodically once in month.

\section{Pathogenicity of Ganoderma isolates}

A pot culture experiment was laid out at Agriculture Research Station, Konehally, Tiptur to test virulence of Ganoderma isolates on coconut seedlings through soil inoculation during the year 2015-16. Nine Ganoderma isolates of coconut $\left[\mathrm{CG}_{1}, \mathrm{CG} 3, \mathrm{CG}_{4}, \mathrm{CG}_{7}\right.$, $\mathrm{CG}_{8}, \mathrm{CG}_{11}, \mathrm{CG}_{13}, \mathrm{CG}_{14}$ and $\mathrm{CG}_{19}$ ] were mass multiplied separately on sorghum grains in poly bags and were used for soil inoculation by mixing with $200 \mathrm{~g} /$ pot with the potting mixture at the time of planting. A control was maintained without inoculating Ganoderma isolates. All the treatments were replicated four times and arranged in a randomized block design. The seedlings used for virulence experiment were Tiptur tall and were 6-8 months old.

\section{Disease severity index (DSI)}

The plants were scored for disease class on a scale of 0 to 4 (Table 3 ). After recording the disease class for each control and treatment, the Disease Severity Index (DSI) was calculated using a modified method of Abdullah et al., (2003) and Ilias (2000).

The DSI was calculated at monthly intervals based on the following formula:

$$
\begin{array}{cc}
\text { Disease Severity Index } & \Sigma(\mathrm{A} \times \mathrm{B}) \times \\
(\mathrm{DSI})= & \frac{100}{\Sigma \mathrm{B} \times 4}
\end{array}
$$

Where:

A - Disease class $(0,1,2,3$ or 4$)$

B - Number of plants showing that disease class per treatment 


\section{Results and Discussion}

\section{Survey for the incidence of Ganoderma wilt of coconut}

Among four districts surveyed, Tumkur recorded maximum incidence of Ganoderma wilt $(16.75 \%)$ followed by Chitradurga and Hassan which accounted 14.86 and 11.12 per cent incidence respectively. Chikanayakanahally Taluk of Tumkur district accounted maximum (29.95 \%) incidence followed by Tiptur and Arsikere by accounting 25.05 and 21.10 per cent respectively. However, the minimum (3.89) per cent incidence was observed in Kadur Tq. of Chikamagalore district (Table 4).

The garden wise incidence of Ganoderma wilt ranged from 0 to 47.00 per cent in four districts surveyed wherein, maximum incidence was recorded in Shetikere $(47.00$ $\%)$ followed by Thimanahally village (38.00 $\%$ ) of Chikanayakanahally Tq. of Tumkur district and Haranahally (31.00\%) village of Arsikere Tq. of Hassan Dist among 356 villages/ gardens surveyed.

The Ganoderma wilt incidence with respect major soil type and agronomic practices were recorded that, maximum incidence (14.28 $\%)$ was observed in sandy soils followed red soils (13.52 \%). As well, the canal waterirrigated gardens accounted maximum (19.20 $\%$ ) incidence compared to gardens under bore well water and rainfed conditions. Similarly, gardens under flood irrigation recorded maximum $(17.78 \%)$ incidence compared to gardens under drip, basin/sprikler methods of irrigation. The gardens under regular cultivation recoded maximum incidence compared to un cultivated gardens (Table 5). The disease incidence with respect to age of the palms revealed that maximum $(14.92 \%)$ incidence was noticed in age group of 30-50 years followed by 15-30 years of age.

\section{Incidence of Ganoderma wilt with respect agronomic practices}

The survey results indicated that 10 to 40 years old palms were normally affected by Ganoderma wilt disease. Though the disease incidence was observed both in irrigated and rainfed coconut gardens, more incidence was observed where there was regular inter cultivation. Srinivasulu et al., (2003) reported that the incidence was observed maximum (up to $62.50 \%$ ) in coconut gardens raised in sandy and red soils in coastal district of Andhra Pradesh, while negligible (1.21\%) and no incidence was observed in black soils, paddy bunds or fish or prawn pond bunds.

They also stated that, number of rainy days and rainfall had a negative relationship with the spread of basal stem rot disease of coconut and spread of the disease was completely checked by water stagnation.

\section{Ganoderma wilt of coconut with respect to cropping system/pattern}

Various types of coconut based cropping pattern/systems and sole crop of coconut and arecanut were observed during course of investigation. Incidence of Ganoderma wilt (BSR) disease with respect to different cropping pattern/systems were observed and the results revealed that BSR disease incidence was noticed in all most all the cropping patterns/systems and in sole crop of coconut and arecanut (Table 6). The incidence of disease was more with coconut and arecanut intercropping compared to sole crop.

However, the percentage of incidence with particular cropping pattern/system varies greatly from garden to garden. Further, to confirm the influence of various cropping pattern/system on incidence and severity of disease may require long range systematic study. The most common symptoms observed 
during course of investigation are yellowing of outer whorl leaves, reduction in crown size, drooping of leaves, bleeding on trunk and formation of brackets on dead and severely affected palms (Fig. 2).

Some of common ITK practices practiced by the farmers for the management of basal stem rot/stem bleeding disease are pasting red earth and lime on trunk of the palm, chiseling the bleeding patch and pasting of lime paste, pasting of tar on bleeding patch, chiseling around the trunk at above the bleeding patch (thinking that bleeding patch should not go up), burning the bleeding patch with fire and planting rasa kalli (Cactus sp.) at base of the plant, putting nails on trunk etc were observed

\section{Isolation and designation of the causal organism isolates}

Ganoderma sporophore and diseased root bits were found good source for aseptic isolation. The percentage of isolates obtained from sporophore and diseased root bits were 48.27 and 32.25 per cent, respectively in coconut. Similarly, in case of arecanut out of fifty two samples subjected for isolation, Ganoderma was isolated from 21 samples.

The percentage of isolates obtained from sporophore and diseased root bits was 52.94 and 46.42 per cent, respectively (Table 7) and were designated as described under material and methods.

The Ganoderma was not isolated from diseased stem bits/ bark either in coconut or areacnut. The isolated pathogens were identified as Ganoderma sp. based on colony morphology and mycelia characteristics. Bhaskaran et al., (1991) stated that among various diseased samples subjected for isolation G. lucidum and G. applanatum were isolated only from diseased root pieces.

\section{Pathogenicity of Ganoderma isolates}

Virulence of nine Ganoderma isolates of coconut on coconut seedlings was tested in pot culture through soil of sorghum based inoculum. The disease severity index (DSI) values were found non-significant at three and five months after inoculation (MAI) and are found significant at 7 and 9 MAI. Among nine Ganoderma isolates tested $\mathrm{CG}_{11}$ recorded maximum (62.50) DSI at 9 months after inoculation followed by $\mathrm{CG}_{7}$ and $\mathrm{CG}_{8}$ which accounted 56.25 DSI and are on par with each other and are found to be virulent compare to other isolates (Table 8).

Isolate $\mathrm{CG}_{3}$ and $\mathrm{CG}_{19}$ recorded minimum (25) DSI. The leaves of infected plants showed yellowing, browning of leaves starting from outer whorl of leaf and it was followed by chloratic symptoms of leaf and wilting of plants/seedlings were observed in isolate $\mathrm{CG}_{7}, \mathrm{CG}_{8}$ and $\mathrm{CG}_{11}$. The white fungal mass on basal part of the plants was also observed. The cross-section of an infected plant stem showed a necrotic lesion at the vascular region (Fig. 3).

The results clearly revealed that, the virulence of isolates varied greatly from isolate to isolate and isolate $\mathrm{G}_{11}(\mathrm{CN})$ was found most virulent among 9 isolates tested. The causal organism was re-isolated from the infected seedlings and was compared with the original culture. Thus, the pathogenicity of Ganoderma isolates to coconut seedlings (Tiptur tall) was established through soil inoculation technique.

\section{Incidence of Ganoderma wilt}

Incidence of Ganoderma wilt of coconut was observed in all districts surveyed in dry tracts of Karnataka and was becoming major problem limiting production and productivity of palms. The disease has been reported from 
various places all over the tropical world viz., India, Sri Lanka, West Indies, Seycheles, Guam, etc. Though the disease was first recorded by Dr. Butler in the beginning of $20^{\text {th }}$ Century, and later by Venkatanarayan (1936) from Karnataka, a severe outbreak occurred in 1952 in Thanjavur district of Tamil Nadu. Till 1960s, the disease was confined to the coastal areas of Tamil Nadu. In 1978, the disease was noticed in all the districts of Tamil Nadu (Bhaskaran and Ramanathan, 1984).

In severely affected gardens in Thanjavur district, the incidence was as high as 31 per cent (Bhaskaran et al., 1984). Apart from Tamil Nadu, the disease is reported from Andhra Pradesh (Srinivasalu et al., 2003), Karnataka (Govindu et al., 1983 and Palanna et al., 2009), and Kerala, Maharastra, Gujarath and Orissa (Bhaskaran et al., 1994; Wilson et al., 1987). Ganoderma sp. has a wide host range attacking variety of palms and several forest, avenue and fruit trees (Govindu et al., 1983; Bhaskaran et al., 1994).

The fungus usually attacks old or weak palms growing under unfavorable conditions. The pathogen is a soil dweller inhabiting dead as well as living plant material in the soil, enters through the wounds and disease spread mainly through soil. Basal stem rot disease incidence ranged from 6.06 to 36.15 per cent in Arsikere Taluk of Karnataka (Naik et al., 2000)

\section{Incidence of Ganoderma wilt with respect agronomic practices}

The disease incidence noticed in all most all soil type and cropping systems. The garden to garden incidence varied with different agronomic practices.The present findings were in accordance with the findings of Garett (1944) and Stover (1953) who stated that most of root infecting fungi viz Fusarium spp. and Ganoderma lucidum were aerobes favored by light soils and low soil moisture. When method of irrigation and water source is considered, BSR disease incidence was noticed in all types/methods of irrigation and water sources. Maximum incidence was noticed in gardens with flood irrigation by canal water. Bhaskaran et al., (1978) stated that irrigation alone was infective in reducing the intensity of disease. The disease was more severe during summer months which might be due to the lack of soils moisture during these months (Vijayan and Natarajan et al., 1997 and Ramaswami et al., 1997). When, cultivated and uncultivated gardens is considered more BSR incidence was noticed in cultivated gardens compare to uncultivated gardens. It may be due to the fact that, during cultivation spread of soil/inoculum form infected palm to healthy palms and root damage may helped the pathogen to cause the disease.

Canal irrigated gardens accounted maximum the incidence of foot rot caused by Ganoderma spp. (12.7\%) compared with bore-well irrigated gardens and those under rainfed conditions. Similarly, gardens under flood irrigation recorded 15.1 per cent of maximum incidence compared to gardens under drip, basin/sprinkler irrigation systems and gardens under regular cultivation recorded the maximum incidence compared to uncultivated gardens (Palanna et al., 2018)

\section{Pathogenicity of Ganoderma isolates}

All isolates tested in our study excreted different degrees of virulence. Artificial infection of plants/seedlings by contact with the inoculum block carrying $G$. boninense FA 5201 is an effective strategy for inducing the infection (Breton et al., 2006). The present results revealed that there is variation in level of aggressiveness of different isolates of 
coconut and arecanut and were in accordance with findings of Breton et al., (2006) who reported that there were variations in the level of aggressiveness in seven $G$. boninense isolates collected from three different estates in Indonesia. Information related to different level of virulence among Ganoderma isolates of coconut and arecanut collected from various locations in dry tracts of southern Karnataka will be useful for future researchers.

Idris et al., (2004) employed root inoculation method where primary roots of oil palm seedlings in polybag were exposed and inserted into test tubes containing various Ganoderma spp. isolates grown in POPW medium (mixture of paddy, oil palm wood sawdust, supplemented with sucrose, ammonium sulphate, calcium sulphate, and bacto peptone). Of a total of 344 isolates tested, 304 isolates were found pathogenic and 40 isolates were nonpathogenic.

Khairudin et al., (1991) reported 100 per cent success in infecting oil palm by wrapping bare roots of seedlings over rubber wood blocks (RWB) $\left(6 \times 6 \times 12 \mathrm{~cm}\right.$ or $\left.432 \mathrm{~cm}^{3}\right)$ pre-inoculated with Ganoderma boninense. Most of the literatures reported that the signs or symptoms for diseased seedlings only manifested approximately 3-4 months after treatments for 4 to 6-month-old seedlings (Breton et al., 2006, Nur Ain Izzati and Abdullah, 2008, Rees et al., 2007).

Table.1 List of major coconut and arecanut growing areas selected for survey in southern Karnataka

\begin{tabular}{|c|c|c|c|c|c|}
\hline $\begin{array}{l}\text { Sl. } \\
\text { No. }\end{array}$ & $\begin{array}{l}\text { Name of } \\
\text { District }\end{array}$ & $\begin{array}{c}\text { Name of } \\
\text { Taluk }\end{array}$ & $\begin{array}{c}\text { Number } \\
\text { of } \\
\text { Villages }\end{array}$ & $\begin{array}{l}\text { Number } \\
\text { gardens } \\
\text { covered }\end{array}$ & $\begin{array}{c}\text { Total Number } \\
\text { of Palms } \\
\text { observed }\end{array}$ \\
\hline \multirow[t]{3}{*}{1} & Chitradurga & i) Hosdurga & 198 & 17 & 1700 \\
\hline & & ii) Holalkere & 166 & 14 & 1400 \\
\hline & & iii)Hiriyur & 164 & 14 & 1400 \\
\hline \multicolumn{3}{|r|}{ Sub total } & 528 & 45 & 4500 \\
\hline \multirow[t]{4}{*}{2} & Hassan & i) Arsikere & 340 & 30 & 3000 \\
\hline & & ii) Chanarayapatana & 375 & 33 & 3300 \\
\hline & & iii) Beluru & 384 & 33 & 3300 \\
\hline & & iv) Hassan & 391 & 34 & 3400 \\
\hline \multicolumn{3}{|r|}{ Sub total } & 1490 & 130 & 13000 \\
\hline \multirow[t]{5}{*}{3} & Tumkur & i) Tiptur & 231 & 20 & 2000 \\
\hline & & ii) Chikanayakanahally & 234 & 21 & 2100 \\
\hline & & iii) Tumkur & 373 & 33 & 3300 \\
\hline & & iv) Turuvekere & 243 & 21 & 2100 \\
\hline & & v) Gubbi & 346 & 30 & 3000 \\
\hline \multicolumn{3}{|r|}{ Sub Total } & 1427 & 125 & 12500 \\
\hline \multirow[t]{3}{*}{4} & Chikkamagalore & i) Kadur & 314 & 28 & 2800 \\
\hline & & ii) Tarikere & 250 & 22 & 2200 \\
\hline & & iii)Narashimarajapura & 59 & 6 & 600 \\
\hline \multicolumn{3}{|r|}{ Sub Total } & 623 & 56 & 5600 \\
\hline \multicolumn{3}{|r|}{ Grand Total } & 4071 & 356 & 35600 \\
\hline
\end{tabular}


Table.2 Identity and designation of Ganoderma isolates of coconut and their source of collection

\begin{tabular}{|c|c|c|c|}
\hline $\begin{array}{l}\text { Sl. } \\
\text { No. }\end{array}$ & $\begin{array}{l}\text { Source of } \\
\text { isolation }\end{array}$ & Place of collection & $\begin{array}{c}\text { Identity and } \\
\text { designation of } \\
\text { Ganoderma isolates }\end{array}$ \\
\hline \multicolumn{4}{|c|}{ Coconut } \\
\hline 1 & Sporocarps & Karekodihally, ArsikereTq. Hassan Dist. & $\mathrm{CG}_{1}$ \\
\hline 2 & Root Samples & Haranahally, ArsikereTq. Hassan Dist. & $\mathrm{CG}_{2}$ \\
\hline 3 & Sporocarps & Vittalapura, ArsikereTq. Hassan Dist. & $\mathrm{CG}_{3}$ \\
\hline 4 & Sporocarps & Nagenakoppalu, CR Pattana Tq. Hassan Dist. & $\mathrm{CG}_{4}$ \\
\hline 5 & Root Sample & Badarahally, Channarayapattana Tq. Hassan Dist. & $\mathrm{CG}_{5}$ \\
\hline 6 & Root Samples & Belagralli, Tiptur Tq. Tumkur Dist. & $\mathrm{CG}_{6}$ \\
\hline 7 & Sporocarps & Hindiskere, Tiptur Tq. Tumkur Dist. & $\mathrm{CG}_{7}$ \\
\hline 8 & Sporocarps & Thimmanahali, C.N.Halli Tq. Tumkur Dist. & $\mathrm{CG}_{8}$ \\
\hline 9 & Sporocarps & Anesidri, Hiriyur Tq. Tumkur Dist. & $\mathrm{CG}_{9}$ \\
\hline 10 & Root Sample & Dharmapura(H), Hiriyur Tq. Chitradurga Dist. & $\mathrm{CG}_{10}$ \\
\hline 11 & Root Samples & Venglapura, Hosdurga Tq. Chitradurga Dist. & $\mathrm{CG}_{11}$ \\
\hline 12 & Sporocarps & Shettihalli, HosdurgaTq. Chitradurga Dist. & $\mathrm{CG}_{12}$ \\
\hline 13 & Root Samples & Thirumalapura Holalkere Tq. Chitradurga Dist. & $\mathrm{CG}_{13}$ \\
\hline 14 & Sporocarps & Thalakatta, HosdurgaTq. Chitradurga Dist. & $\mathrm{CG}_{14}$ \\
\hline 15 & Sporocarps & Vaderahalli, Holalkere Tq. Chitradurga Dist. & $\mathrm{CG}_{15}$ \\
\hline 16 & Root Sample & Doddanaramangala, Tumkur Tq. Tumkur Dist. & $\mathrm{CG}_{16}$ \\
\hline 17 & Root Samples & Kodipalya, Tumkur Tq. Tumkur Dist & $\mathrm{CG}_{17}$ \\
\hline 18 & Sporocarps & Shettikere, C.N.Halli Tq. Tumkur Dist. & $\mathrm{CG}_{18}$ \\
\hline 19 & Sporocarps & Hullekere, Turvekere Tq. Tumkur Dist. & $\mathrm{CG}_{19}$ \\
\hline 20 & Sporocarps & Thyagaturu, Gubbi Tq. Tumkur Dist. & $\mathrm{CG}_{20}$ \\
\hline 21 & Sporocarps & Upparanahally, HassanTq. Hassan Dist. & $\mathrm{CG}_{21}$ \\
\hline 22 & Root Samples & Bhuvanahally,HassanTq. Hassan Dist. & $\mathrm{CG}_{22}$ \\
\hline 23 & Sporocarps & Bandarikatte,BeluruTq. Hassan Dist. & $\mathrm{CG}_{23}$ \\
\hline 24 & Root Samples & Narasipura, BeluruTq. Hassan Dist. & $\mathrm{CG}_{24}$ \\
\hline
\end{tabular}


Table.3 Disease scale for Ganoderma wilt 0-4 (Abdullah et al., 2003; Ilias 2000)

\begin{tabular}{|c|l|}
\hline Disease class & \multicolumn{1}{|c|}{ Signs and symptoms of infection } \\
\hline $\mathbf{0}$ & $\begin{array}{l}\text { Healthy plants with green leaves without appearance of fungal } \\
\text { mycelium on any part of plants }\end{array}$ \\
\hline $\mathbf{1}$ & $\begin{array}{l}\text { Appearance of white fungal mass on any part of plants, with or without } \\
\text { chlorotic leaves }\end{array}$ \\
\hline $\mathbf{2}$ & $\begin{array}{l}\text { Appearance of fungal mass/ mycelium on any part of plants with } \\
\text { chlorotic leaves (1-3 leaves) }\end{array}$ \\
\hline $\mathbf{3}$ & $\begin{array}{l}\text { Appearance of fungal mass/ mycelium on any part of plants with } \\
\text { chlorotic leaves (> } 3 \text { leaves) }\end{array}$ \\
\hline $\mathbf{4}$ & Formation of well-developed basidioma and the plants dried/wilted \\
\hline
\end{tabular}

Table.4 Incidence of Ganoderma wilt coconut in southern Karnataka

\begin{tabular}{|c|c|c|c|c|c|}
\hline $\begin{array}{l}\text { Sl. } \\
\text { No. }\end{array}$ & District & Taluk & $\begin{array}{l}\text { No Gardens } \\
\text { Observed }\end{array}$ & $\begin{array}{c}\text { Number of } \\
\text { palms observed }\end{array}$ & $\begin{array}{c}\text { Disease } \\
\text { incidence }(\%)\end{array}$ \\
\hline \multirow[t]{4}{*}{1} & Chitradurga & i) Hosdurga & 17 & 1700 & 17.58 \\
\hline & & ii) Holalkere & 14 & 1400 & 20.35 \\
\hline & & iii)Hiriyur & 14 & 1400 & 6.07 \\
\hline & & Sub total & 45 & 4500 & 14.86 \\
\hline \multirow[t]{5}{*}{2} & Hassan & i) Arsikere & 30 & 3000 & 21.10 \\
\hline & & ii) C R Patna & 33 & 3300 & 6.34 \\
\hline & & iii) Beluru & 33 & 3300 & 7.81 \\
\hline & & iv) Hassan & 34 & 3400 & 10.17 \\
\hline & & Sub total & 130 & 13000 & 11.12 \\
\hline \multirow[t]{6}{*}{3} & Tumkur & i) Tiptur & 20 & 2000 & 25.05 \\
\hline & & ii) $\mathrm{C} \mathrm{N}$ hally & 21 & 2100 & 29.95 \\
\hline & & iii) Tumkur & 33 & 3300 & 9.52 \\
\hline & & iv) Turuvekere & 21 & 2100 & 14.67 \\
\hline & & v) Gubbi & 30 & 3000 & 11.40 \\
\hline & & Sub Total & 125 & 12500 & 16.75 \\
\hline \multirow[t]{4}{*}{4} & $\begin{array}{l}\text { Chickkamag } \\
\text { alore }\end{array}$ & i) Kadur & 28 & 2800 & 3.89 \\
\hline & & ii) Tarikere & 22 & 2200 & 3.90 \\
\hline & & iii) NR Pura & 06 & 600 & 8.34 \\
\hline & & Sub Total & 56 & 5600 & 4.37 \\
\hline
\end{tabular}

* Number of palms observed 
Table.5 Incidence of Ganoderma wilt of coconut and arecanut with respect to soil types and different agronomic practices in southern Karnataka

\begin{tabular}{|c|c|c|}
\hline Sl. No. & Particulars & $\begin{array}{c}\text { Disease Incidence } \\
(\%)\end{array}$ \\
\hline \multirow[t]{4}{*}{1} & Soil type & \\
\hline & a) Red soil & 13.52 \\
\hline & b) Black soil & 8.18 \\
\hline & c) Sandy soil & 14.28 \\
\hline \multirow[t]{4}{*}{2} & Water source & \\
\hline & a) Bore well & 13.96 \\
\hline & b) Canal & 19.20 \\
\hline & c) Rainfed & 4.53 \\
\hline \multirow[t]{5}{*}{3} & Method of irrigation & \\
\hline & a) Drip & 6.65 \\
\hline & b) Flood irrigation & 17.78 \\
\hline & c) Basin method /Sprinkler & 10.62 \\
\hline & d) Rainfed & 5.08 \\
\hline \multirow[t]{3}{*}{4} & Cultivation & \\
\hline & a) Cultivated & 15.23 \\
\hline & b) Un cultivated & 4.34 \\
\hline \multirow[t]{5}{*}{5} & Age of the palms (Years ) & \\
\hline & a) $>15$ & 6.76 \\
\hline & b) $15-30$ & 14.27 \\
\hline & c) $30-50$ & 14.92 \\
\hline & d) $<50$ & 9.66 \\
\hline
\end{tabular}

Table.6 Effect of different cropping pattern/system on Incidence of Ganoderma wilt disease of coconut in southern Karnataka

\begin{tabular}{|c|l|l|c|}
\hline $\begin{array}{c}\text { Sl. } \\
\text { No. }\end{array}$ & \multicolumn{1}{|c|}{ District } & \multicolumn{1}{|c|}{ Cropping pattern observed during survey } & $\begin{array}{c}\text { Incidence } \\
\text { of BSR }\end{array}$ \\
\hline $\mathbf{1}$ & Chitradurga & i) Coconut alone & + \\
\hline & & ii) Arecanut alone & + \\
\hline & & iii) Coconut + Horticulture crops (Arecanut/Banana) & + \\
\hline & & $\begin{array}{l}\text { iv) Coconut + Vegetables } \\
\text { (Tomato/Brinjol/Chilli) }\end{array}$ & + \\
\hline & & v) Coconut + Pulses (Cowpea/Greengram) & + \\
\hline $\mathbf{2}$ & Hassan & $\begin{array}{l}\text { vi) Coconut + Fodder crops (Maize/Sorgum/Co-3) } \\
\text { i) Coconut alone }\end{array}$ & + \\
\hline & & ii) Arecanut alone & + \\
\hline & & iii) Coconut + Arecanut & + \\
\hline & & iv) Coconut + Vegetables & + \\
\hline
\end{tabular}




\begin{tabular}{|c|c|c|c|}
\hline & & (Tomato/Brinjol/Chilli) & \\
\hline & & $\begin{array}{l}\text { v) Coconut + Pulses/Green manure (Cowpea/Green } \\
\text { gram) }\end{array}$ & + \\
\hline & & vi) Coconut + Fodder crops (Maize/Sorgum/Co-3) & + \\
\hline & & $\begin{array}{l}\text { vii) Coconut + Flower crops } \\
\text { (Marigold/Chrysanthimum) }\end{array}$ & + \\
\hline & & viii) Coconut + Spice crops (Turmeric/Zinger) & + \\
\hline \multirow[t]{7}{*}{3} & Tumkur & i) Coconut alone & + \\
\hline & & ii) Arecanut alone & + \\
\hline & & iii) Coconut + Arecanut & +++ \\
\hline & & $\begin{array}{l}\text { iv) Coconut + Vegetables/Leafy vegetables } \\
\text { (Tomato/Brinjol/Chilli/Beans/gouards) }\end{array}$ & + \\
\hline & & v) Coconut + Fodder crops (Maize/Sorgum/Co-3) & + \\
\hline & & $\begin{array}{l}\text { vi) Coconut + Flower crops } \\
\text { (Marigold/Chrysanthimum) }\end{array}$ & + \\
\hline & & vii) Coconut + Betel vine & + \\
\hline \multirow[t]{7}{*}{4.} & Chikamagalore & i) Coconut alone & + \\
\hline & & ii) Arecanut alone & + \\
\hline & & iii) Coconut + Arecanut & ++ \\
\hline & & $\begin{array}{l}\text { iv) Coconut + Vegetables/Leafy vegetables } \\
\text { (Tomato/Brinjol/Chilli/Beans/gaurds/ cucumber) }\end{array}$ & + \\
\hline & & v) Coconut + Fodder crops (Maize/Sorgum/Co-3) & + \\
\hline & & $\begin{array}{l}\text { vi) Coconut + Flower crops } \\
\text { (Marigold/Chrysanthimum) }\end{array}$ & + \\
\hline & & vii) Coconut + Betel vine & + \\
\hline
\end{tabular}

Note: + Ganoderma wilt incidence noticed

Table.7 Ganoderma isolates isolated from coconut

\begin{tabular}{|c|c|c|c|c|}
\hline $\begin{array}{l}\text { Sl. } \\
\text { No. }\end{array}$ & Type of sample & $\begin{array}{c}\text { Number of } \\
\text { sample }\end{array}$ & $\begin{array}{c}\text { Ganoderma } \\
\text { obtained }\end{array}$ & $\begin{array}{c}\text { \% isolates } \\
\text { obtained }\end{array}$ \\
\hline \multicolumn{5}{|c|}{ I COCONUT } \\
\hline 1 & Sporophore & 29 & 14 & 48.27 \\
\hline 2 & Root samples & 31 & 10 & 32.25 \\
\hline 3 & Disease Stem Bits/Bark & 10 & 00 & 0.00 \\
\hline \multicolumn{2}{|r|}{ Total } & 70 & 24 & -- \\
\hline
\end{tabular}


Table.8 Virulence of Ganoderma isolates of coconut to coconut seedlings

\begin{tabular}{|c|c|c|c|c|c|}
\hline \multirow{2}{*}{$\begin{array}{l}\text { Sl. } \\
\text { No. }\end{array}$} & \multirow[t]{2}{*}{ Isolates } & \multicolumn{4}{|c|}{ Disease Severity Index (DSI) Months after inoculation (MAI)* } \\
\hline & & 3 & 5 & 7 & 9 \\
\hline 1 & $\mathrm{CG}_{1}$ & $0(0.45)$ & $0(0.45)$ & $12.50(15.23)$ & $31.25(30.12)$ \\
\hline 2 & $\mathrm{CG}_{3}$ & $0(0.45)$ & $0(0.45)$ & $12.50(11.58)$ & $25.00(26.36)$ \\
\hline 3 & $\mathrm{CG}_{4}$ & $0(0.45)$ & $6.25(7.84)$ & $25.00(26.36)$ & $50.00(45.00)$ \\
\hline 4 & $\mathrm{CG}_{7}$ & $0(0.45)$ & $6.25(7.84)$ & $31.25(33.75)$ & $56.25(48.75)$ \\
\hline 5 & $\mathrm{CG}_{8}$ & $0(0.45)$ & $0(0.45)$ & $37.50(37.50)$ & $56.25(48.75)$ \\
\hline 6 & $\mathrm{CG}_{11}$ & $0(0.45)$ & $12.50(15.23)$ & $37.50(37.50)$ & $62.50(52.50)$ \\
\hline 7 & $\mathrm{CG}_{13}$ & $0(0.45)$ & $0(0.45)$ & $12.50(15.23)$ & $37.50(37.50)$ \\
\hline 8 & $\mathrm{CG}_{14}$ & $0(0.45)$ & $6.25(7.84)$ & $12.50(15.23)$ & $31.25(33.75)$ \\
\hline 9 & $\mathrm{CG}_{19}$ & $0(0.45)$ & $0(0.45)$ & $6.25(15.23)$ & $25.00(26.36)$ \\
\hline 10 & Control & $0(0.45)$ & $0(0.45)$ & $0(0.45)$ & $0(0.45)$ \\
\hline & SEm \pm & - & - & 204.64 & 187.86 \\
\hline & $D(p=0.05)$ & NS & NS & 20.759 & 19.885 \\
\hline & CV (\%) & - & - & 68.755 & 39.218 \\
\hline
\end{tabular}

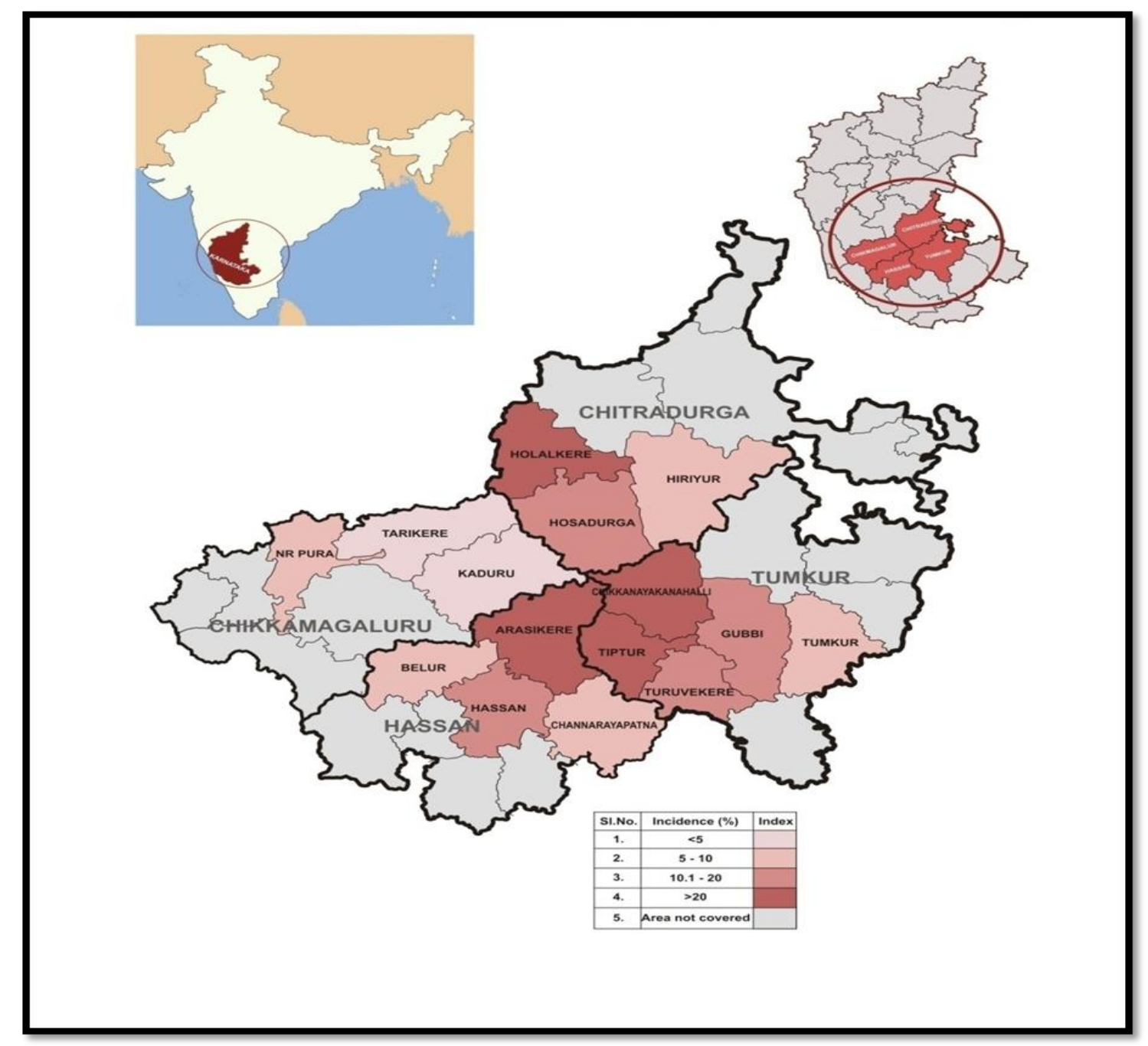

Fig.1 Disease hot spots map of Ganoderma wilt of coconut in southern Karnataka 


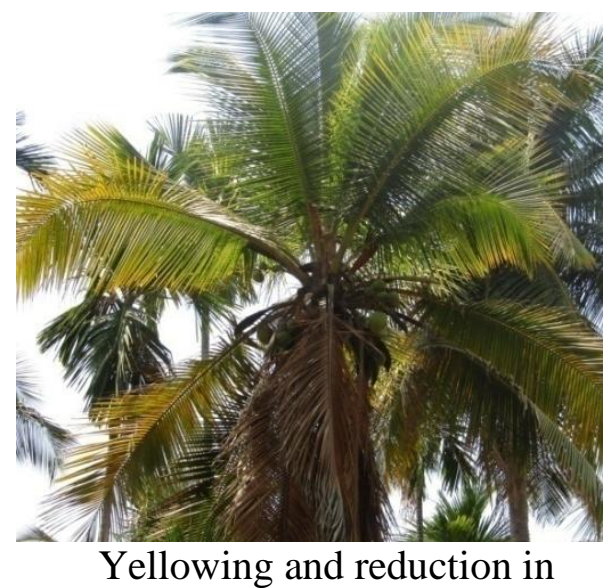

crown size
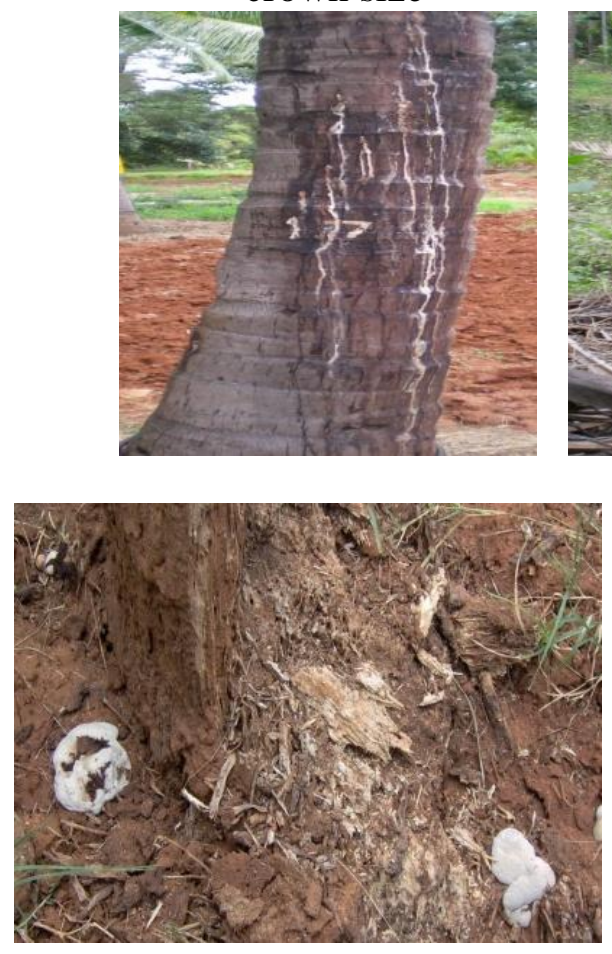
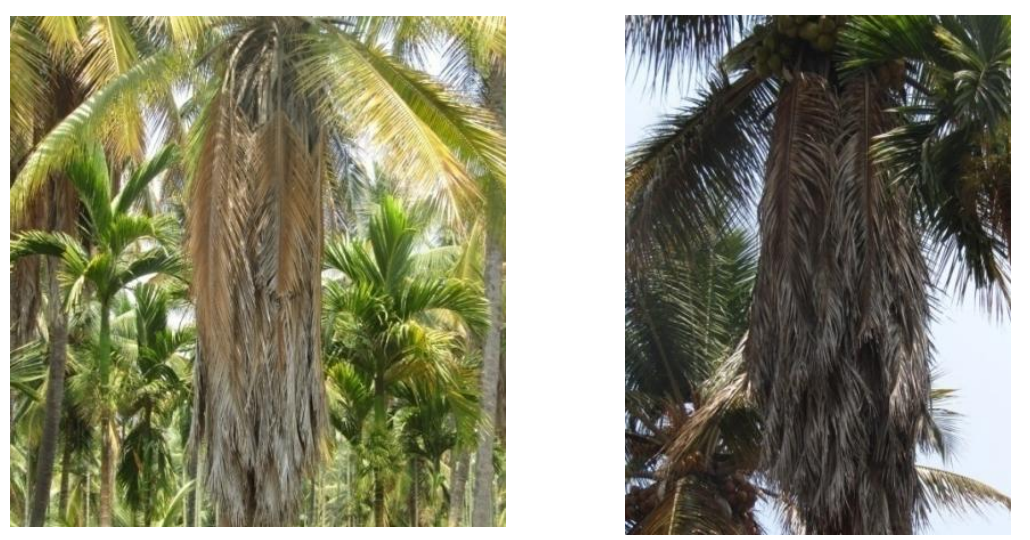

Drooping of leaves around the crown and skirt formation

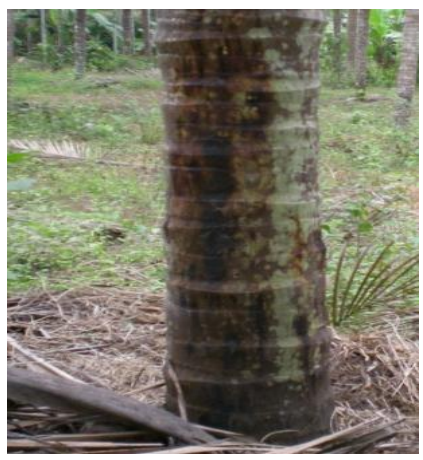

Stem Bleeding
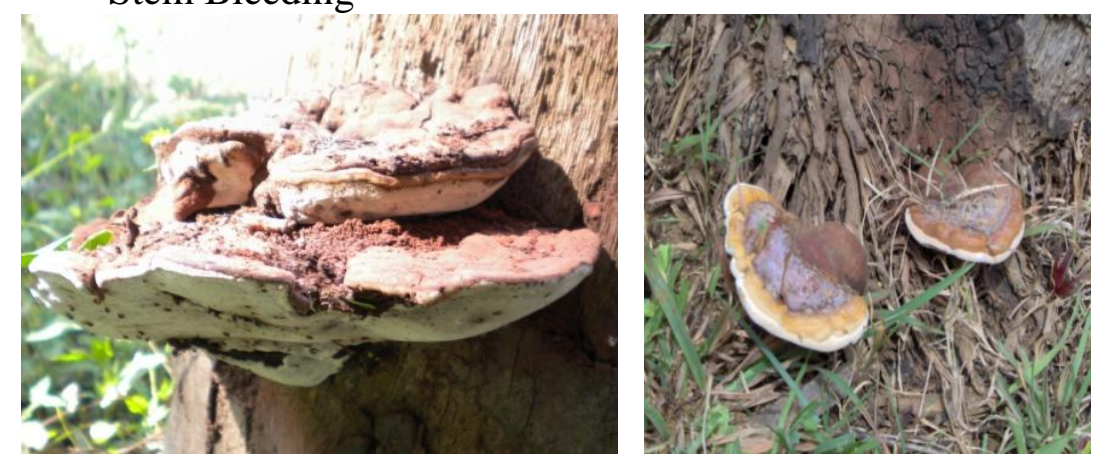

Sporocarps at the infected tree base
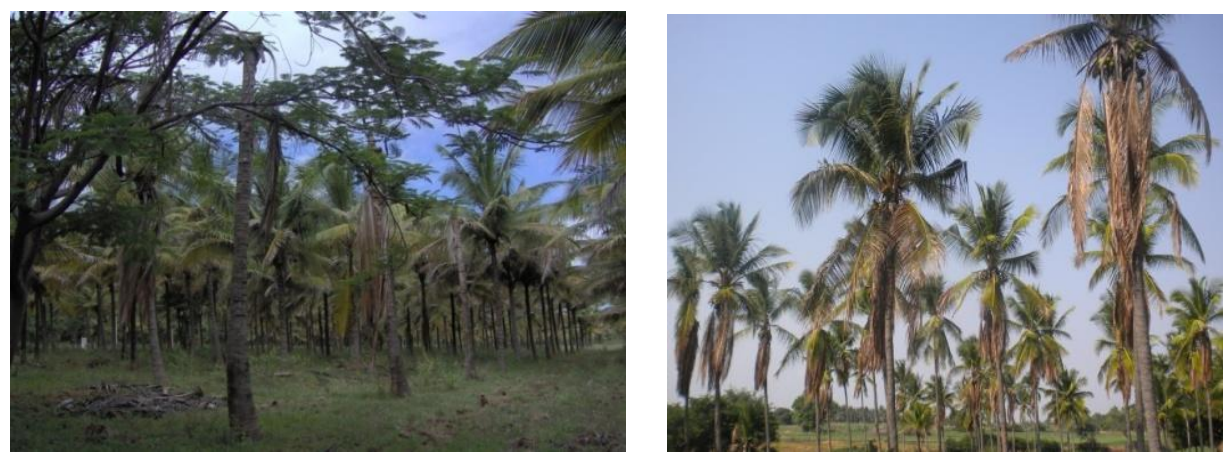

A field view of affected coconut garden

Fig.2 Symptoms of Ganoderma wilt in coconut 


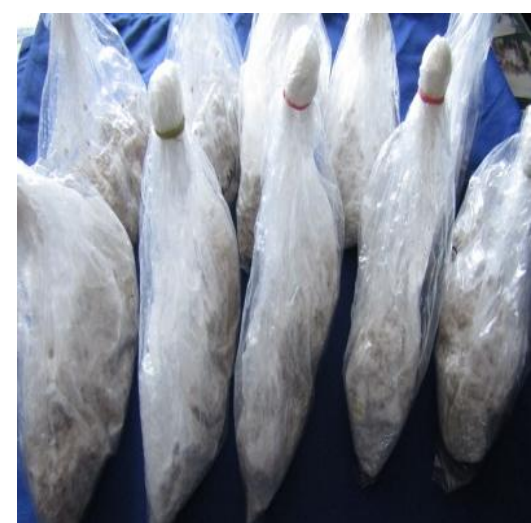

Gaint culture of Ganoderma multiplication on sorghum

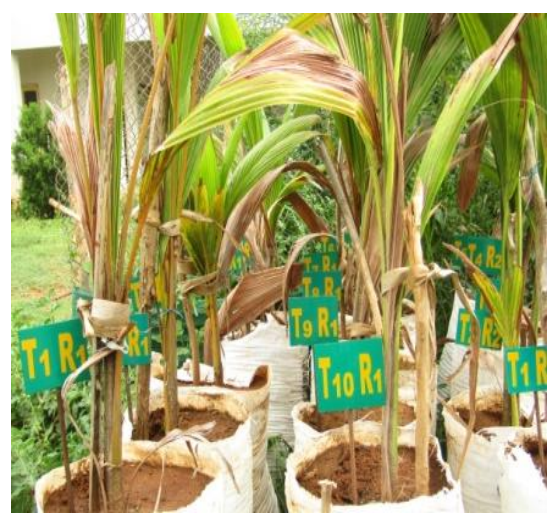

An experimental view of virulence of Coconut Ganoderma isolates

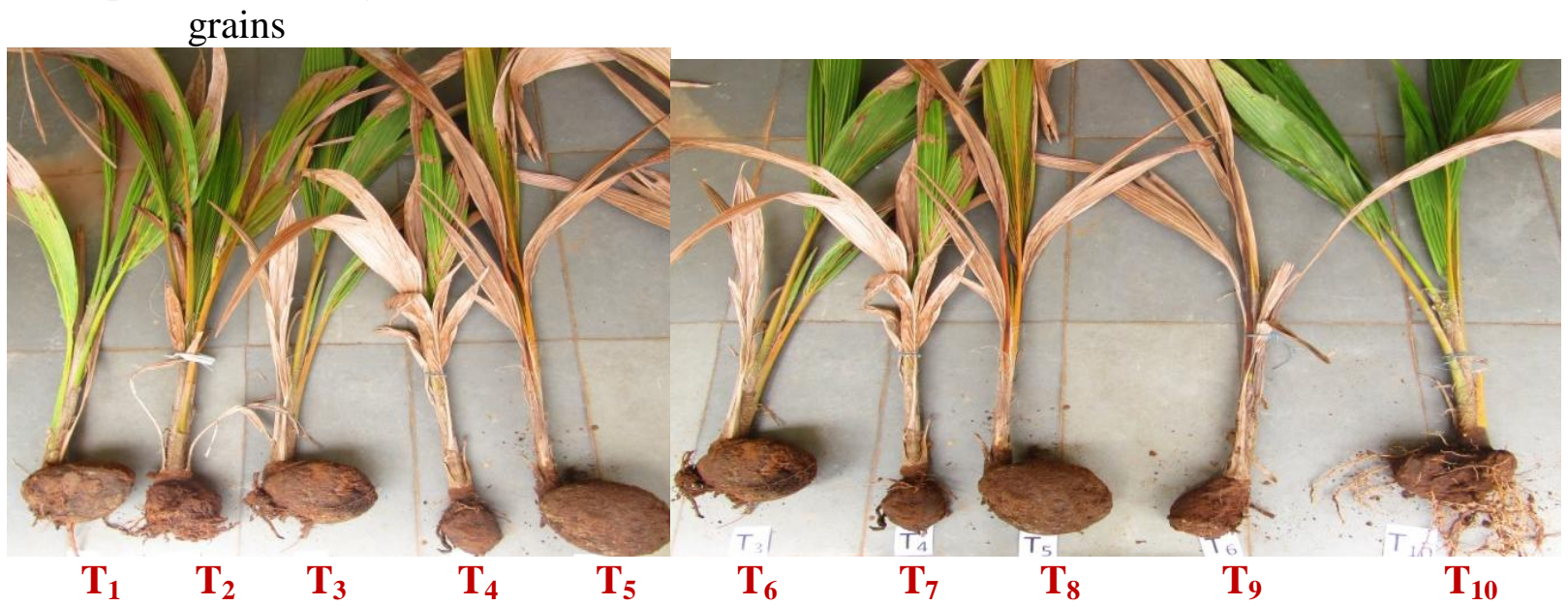

Seedlings showing infection by different isolates of Coconut (Ganoderma isolate)
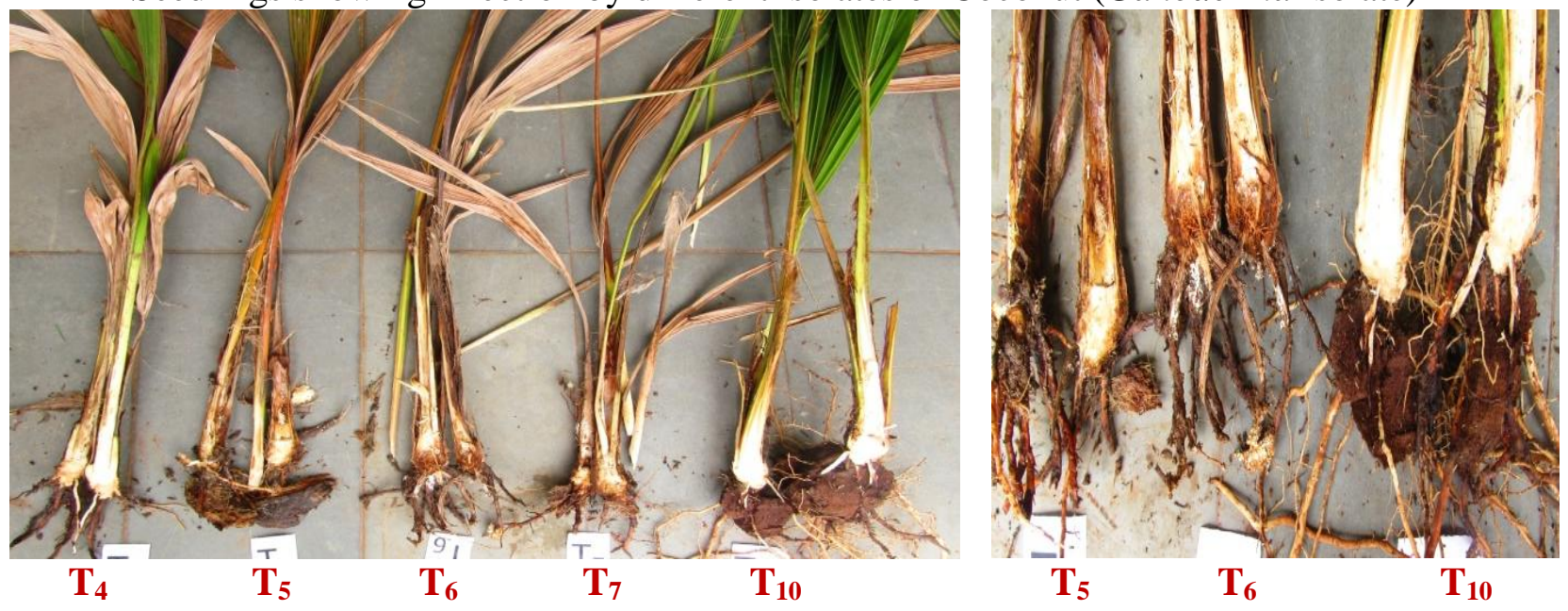

Cross section of infected seedlings

Fig.3 Virulence of Ganoderma isolates of coconut on coconut seedlings (Tiptur tall)

Note: $\quad \mathrm{T}_{1}=\mathrm{CG}_{1}, \mathrm{~T}_{2}=\mathrm{CG}_{3}, \mathrm{~T}_{3}=\mathrm{CG}_{4}, \mathrm{~T}_{4}=\mathrm{CG}_{7}, \mathrm{~T}_{5}=\mathrm{CG}_{8}, \mathrm{~T}_{6}=\mathrm{CG}_{11}, \mathrm{~T}_{7}=\mathrm{CG}_{13}, \mathrm{~T}_{8}=\mathrm{CG}_{14}, \quad \mathrm{~T}_{9}=$ $\mathrm{CG}_{19}, \mathrm{~T}_{10}=$ Control 
However, in this study, the appearance initial infection symptom was noted in few isolates 3-4 months after inoculation. This also could be due to difference in aggressiveness of different isolates used in the study.

Similar results were also reported by Kok et al., 2013, reported that, there was no significant difference in mean disease severity index (DSI) among the 14 different treatments at 8 weeks after artificial inoculation in oil palms. Variations in the degree of virulence for 12 different $G$. boninense isolates tested in this study ranged from highly virulence to least virulence. Virulence of 10 Ganoderma isolates of arecanut tested under pot culture revealed that isolate $\mathrm{AG} 9$, recorded maximum disease severity index (75 DSI) nine months after inoculation followed by $\mathrm{AG}_{22}$ and $\mathrm{AG}_{4}$ which accounted 68.8 DSI each (Palanna et al., 2018).

All Ganoderma isolates collected from various locations in southern dry tracts of Karnataka were found to demonstrate different degree of virulence ranging from highly pathogenic to least pathogenic. Therefore, it is crucial to incorporate more than one isolate into any researchers on screening for Ganoderma resistance or tolerance planting materials, searching for potential biological control agents, and studying bitrophic or tri-trophic interactions, such as pathogen-host or beneficial microbial agent, pathogen and host plant relationships.

The present study revealed incidence Ganoderma wilt of coconut, caused by Ganoderma spp. is emerging as a serious threat, which results in drastic reduction in production and productivity of the palms. Since the disease is soil-borne, infection takes place through roots and spread mainly through soil and water. Most of the farmers are not aware about cause, symptoms, nature of spread and its management. One of the major aspects to control this disease is to prevent spread of disease from infected palms to healthy ones. Hence, creating awareness among the farmers on various aspects of deadly disease is highly essential for the management and to prevent further spread of disease. The disease incidence of ranged from 0 to 47 per cent in southern dry tracts of Karnataka among 356 gardens surveyed. Ganoderma wilt was more with coconut and arecanut intercropping compared to sole crop and other cropping systems. However, the percentage of incidence with particular cropping system varied greatly from garden to garden. Ganoderma isolates tested for their pathogenicity were found to demonstrate different degree of virulence ranging from highly pathogenic to least pathogenic. Therefore, it is essential to incorporate more than one isolate during screening for Ganoderma disease resistance or tolerance planting materials, searching for potential biological control agents, and studying various interactions, such as pathogen-host or beneficial microbial agent, pathogen and host plant relationships.

\section{Acknowledgement}

The authors gratefully acknowledge AICRP on palms, Agriculture Research Station, Arsikere for proving seedlings and Department of Plant Pathology, University of Agricultural Sciences, GKVK, Bengaluru for providing facilities conduct experiment.

\section{References}

Abdullah, F., Ilias, G.N.M., Nelson, M., Nur Ain Izzati M Z and Umi, K Y., 2003. Disease assessment and the efficacy of Trichoderma as a biocontrol agent of basal stem rot of oil palms. Research Bulletin Science Putra, 11: 31-33.

Bhaskaran, R. and Ramanathan, T., 1984. Occurrence and spread of Thanjavur 
wilt disease of coconut. Indian Coconut Journal, 19 (6): 3-8.

Bhaskaran, R., Ramadoss, N. and Suriachandraselvan, 1991. Pathogenicity of Ganoderma spp. isolated from Tanjavur wilt infected coconut (Cocos nucifera L.). Madras Agriculture Journal, 78 (1-4): 137-138.

Bhaskaran, R., Ramanathan, T. and Ramiah, M., 1984. Chemical control of Thanjavur wilt. Intensive Agriculture, 20:19-21.

Bhaskaran, R., Rethinam, P. and Nambiar, K. K. N., 1994. Ganoderma wilt disease of coconut. Advances in Horticulture Vol.10 - Plantation and Spice Crops Part-2., pp. 898-920.

Bhaskaran, R; Chandrasekar G. and Jaganathan T.,1978. Control of Thanjavur wilt disease of coconut. Food Farming and Agriculture, 10 (4):115116.

Breton, F., Hasan, Y., Hariadi, Z., Lubis and Franqueville De, H., 2006. Characterization of parameters for the development of an early screening test for basal stem rot tolerance in oil palm progenies. Journal of Oil Palm Research. Special Issue: 24-36.

Garett, S. D., 1944. Root Disease Fungi. Chronic Botanica Co., Waltham, Massachusetts 177p.

Govindu, H. C., Rao, A. N. S. and Kesavamurthy, K. V., 1983. Biology of Ganoderma lucidum (Leys.) Karst. and controlof Anabe Roga of coconut. In: Coconut Research and Development (Ed.) Nayar, N.M.]. Wiley Eastern Ltd.,pp. 325-332.

Idris, A. S., Kushairi, A., Ismail, S. and Ariffin, D., 2004. Selection for partial resistance in oil palm progenies to Ganoderma basal stem rot. Journal of Oil Palm Research, 16: 12-18.

Ilias, G. N.M., 2000. Trichoderma and its efficacy as a bio-control agent of basal stem rot of oil palm (Elaeis guineensis Jacq.). [Ph.D. Thesis.] University Putra Malaysia, Selangor, Malaysia.

Khairudin, H., Lim, T. K. and Abdul Razak, A. R., 1991. Pathogenicity of Ganoderma boninense pat. on oil palm seedlings. In: Proceedings of the 1991 PORIM International Congress (Agriculture). Kuala Lumpur, Malaysia: Palm Oil Research Institute of Malaysia, pp. 418-423.

Kok, S.M., Goh, Y. K., Tung, H. J., Goh, K. J., Wong, W. C. and Goh, Y. K., 2013. In vitro growth of Ganoderma boninense isolates on novel palm extract medium and virulence on oil palm (Elaeis guineensis) seedlings. Malaysian Journal of Microbiology, 9(1): 33-42.

Naik, R. G., Palanimuthu, V., Hanumanthappa, $\mathrm{M}$ and Indiresh, $\mathrm{K}$. M., 2000. Prevalence and intensity of basal stem rot disease of coconut in Arsikere taluk of Karnataka. Indian Coconut Journal, 31(1): 8-10.

Nur Ain Izzati, M. Z. and Abdullah, F., 2008. Disease suppression in Ganoderma infected oil palm seedlings treated with Trichoderma harzianum. Plant Protection Science, 44:101-107.

Palanna, K B., Ganesh Naik, R., Basavaraj, T. B., Boraiah, B. and Tyagaraj, N. E., 2009. Etiology and management of coconut basal stem rot (Ganoderma wilt) in sandy soils of Karnataka. Journal of Plantation Crops, 37(1): 2629.

Palanna, K.B., Narendrappa, T., Basavaraj, S. and Shreenivasa, K.R. 2018.Virulence analysis and influence of soil pattern and agronomic practices with respect to Ganoderma foot rot of arecanut in southern Karnataka. Journal of Plantation Crops, 46(1): 21-31

Ramasami, B., Baskaran, R. and Jaganthan, T., 1997. Epidemiology of Tanjavur 
wilt disease of coconut in Tamil Nadu. Food and Agriculture, 9(6): 147-148.

Rees, R. W., Flood, J., Hasan, Y. and Cooper, R. M., 2007. Effects of inoculum potential, shading and soil temperature on root infection of oil palm seedlings by the basal stem rot pathogen Ganoderma boninense. Plant Pathol., 56: 862-870.

Rethinam, P. and Taufikkurahman, L., 2002. Global scenario of coconut oil. Indian Coconut J., 33(7):1-8.

Srinivasalu, B., Aruna, K., Rao, D. V. R. and Hameed Khan, H., 2003. Epidemiology of basal stem rot (Ganoderma wilt) disease of coconut in Andra Pradesh. Indian Journal of Plant Protection, 31(1): 48-50.

Stover, R. H., 1953. The effect of soil moisture on Fusarium species. Canadian Journal of Botany, 31: 693697.

Venkatarayan, S. V., 1936. The biology of Ganoderma lucidum on areca and coconut palms. Phytopathology, 26: 153-175.

Vijayan, K. M. and Natarajan, S., 1972. Some observations on the coconut wilt disease of Tamil Nadu. Coconut Bulletin., 2 (12): 2-4.

Wilson, K. I., Rajan, K. M., Nair, M.C. and Bhaskaran, S., 1987. Ganoderma disease of coconut in Kerala. International symposium on Ganoderma wilt disease on palms and other perennial crops, TNAU, Coimbatore (Abstract) pp. 4-5.

\section{How to cite this article:}

Palanna, K. B., K. R. Shreenivasa, B. Boraiah, S. Basavaraj and Narendrappa, T. 2020. Virulence Analysis and Influence of Soil Type and Agronomic Practices with Respect to Incidence of Ganoderma Wilt of Coconut in Southern Karnataka, India. Int.J.Curr.Microbiol.App.Sci. 9(04): 1527-1543. doi: https://doi.org/10.20546/ijcmas.2020.904.180 